\title{
Prey selectivity of the octocoral Carijoa riisei at Pernambuco, Brazil
}

\author{
PAULA B. GOMES ${ }^{1}$, ANA K.F. LIRA ${ }^{2}$, JEAN-PHILIPPE NAUD ${ }^{3}$, \\ ANDRE M. SANTOS ${ }^{4}$ AND CARLOS D. PÉREZ ${ }^{2,4}$ \\ ${ }^{1}$ Universidade Federal Rural de Pernambuco, Departamento de Biologia, \\ Rua Dom Manuel de Medeiros, s/n, Dois Irmãos, 52171-900 Recife, PE, Brasil \\ ${ }^{2}$ Universidade Federal de Pernambuco, Mestrado em Biologia Animal, \\ Rua Prof. Moraes Rego, 1235, 50670-901 Recife, PE, Brasil \\ ${ }^{3}$ Université de Sherbrooke, Maîtrise en Écologie Internationale, Sherbrooke, QC J1K 2R1, Canada \\ ${ }^{4}$ Universidade Federal de Pernambuco, CAV, \\ Rua do Alto do Reservatório, s/n, Bela Vista, 55608-680 Vitória de Santo Antão, PE, Brasil
}

Manuscript received on January 1, 2011; accepted for publication on October 7, 2011

\begin{abstract}
This study was designed to evaluate prey selection (type and size) by the octocoral Carijoa riisei at Porto de Galinhas beach, Northeast Brazil, relating prey availability in plankton with the content inside polyps. Diatoms and cyanophytes were the predominant items found in both polyp gastric cavity and plankton. A correlation between prey abundance in the plankton and in the gastric cavity of $C$. riisei polyps was observed. Mastogloia $s p$. showed the highest positive electivity index (0.99). Benthonic items were found, with $0.51 \%$ of total consumed preys. The size amplitude of prey items in the plankton was similar to those found inside the polyps, although the mean prey size in the polyps $(112.7 \mu \mathrm{m})$ was significantly lower than the value found in the plankton $(240.5 \mu \mathrm{m})$. Thus, the study indicates some size selectivity in this species or at least size limitation. From the results, we concluded that the octocoral $C$. riisei is an opportunistic polyphagous species in the Brazilian northeast coast, showing suspensivorous passive filtering feeding habit with a preference for small prey items and evidencing its important ecological role in the reefal ecosystem as responsible for bidirectional energy transference between pelagic zones and the benthos.
\end{abstract}

Key words: Alcyonacea, natural feeding, prey selectivity, prey availability, trophic ecology.

\section{INTRODUCTION}

Specific physical properties of the sea water allow living organisms and organic matter to remain suspended in the water column creating a feeding niche for suspensivorous animals, an advantage over

Correspondence to: Paula B. Gomes

E-mail:pgomes@db.ufrpe.br terrestrial animals (Gili and Coma 1998). In shallow coastal ecosystems, benthonic organisms that feed on suspended material are ecologically favorable to communities and populations concerning feeding activity once they are abundant. However, these organisms depend on the availability of feeding resources along the water column since they show little or no motility at all (Ribes et al. 2003). 
Despite the evidences that the feeding ecology of suspensivorous animals is important to the understanding of coastal ecosystems, the knowledge on their natural diet and feeding rates is still poor (Ribes et al. 2003). According to Rossi et al. (2004), studies have focused mainly on suspension feeder behavior rather than on their impact on zoo and phytoplankton.

According to Rossi et al. (2004), studies of the effects of benthonic suspension consumers on plankton abundance in coastal ecosystems have focused mainly on phytoplankton. At the first stage of the trophic web, phytoplankton community is a great contributor for total primary production and the major food source for animals inhabiting the water column and the sediment (Day et al. 1989). Ribes et al. (2003) suggest that the ingestion of phytoplanktonic prey depends both on its size and abundance.

The role of passive feeders has been greatly ignored or assumed minimal. However, many studies and reviews show the importance of these organisms in marine food webs, emphasizing the role of cnidarians (hydroids and octocorals) in shallow water environments (Gili et al. 1997, Gili and Coma 1998, Genzano 2005, Tsounis et al. 2005). These organisms could outstandingly act in the energy transference from plankton to benthos.

In general, octocorals are considered to be carnivorous, a vision supported by the analysis of morphological characters of polyp surfaces (Migné and Davoult 2002). Nevertheless, the aptitude to feed on very small particles such as diatoms and particulate organic matter has been discussed by some authors (Coma et al. 1994). Due to its food capturing method and reduced polyp dimensions, octocorals may be considered passive suspensivorous (Hughes 2001).

The clavularid octocoral Carijoa riisei (Duchassaing and Michelotti 1860) is an abundant species along the Brazilian coast, especially in the Northeast, where some aspects of its ecology were studied (Neves et al. 2007, Souza et al. 2007). A previous study on the trophic ecology of $C$. riisei from Porto de Galinhas beach (Pernambuco, Northeast Brazil) concluded that the species is polyphagous, but with a numerical dominance of phytoplanktonic elements with equitable biomass contribution from phyto and zooplankton (Lira et al. 2009). This study focused only on diet composition without considering the availability of prey in the plankton. Therefore, it was not analyzed the opportunistic character of the species or if it can select prey item or size.

The aim of the present study was to evaluate feeding selectivity of the octocoral Carijoa riisei from Porto de Galinhas beach by correlating prey availability in the plankton and prey abundance in the polyps, and comparing prey size in a oneyear period on two different depth, of the same ecosystem. This study tests the hypothesis that C. riisei is an opportunistic species, using its preys (type and size) in the same proportion that are available in the plankton.

\section{MATERIALS AND METHODS}

\section{STUDY SITE}

The study site is located at Porto de Galinhas beach on Pernambuco coast (Brazil) (8॰30’20" $\mathrm{S}, 35^{\circ} 00^{\prime} 34^{\prime \prime} \mathrm{W}$ ) (Fig. 1). It is characterized as extensive beachrock bands along the shore. The beachrock formations have variable width, length and thickness, and the greater part of it is exposed during low tide. The sampling site is known as 'Piscina dos 8' or 'Boca da Barra', a natural pool up to $8 \mathrm{~m}$ in depth. The samples were collected along a six meters deep, $15 \mathrm{~m}$ wide pool wall, where a population of $C$. riisei is established from surface to bottom. Salinity and temperature remained homogeneous during the whole study, with means of $37.7 \pm 0.56 \%$ and $27.6 \pm 0.41{ }^{\circ} \mathrm{C}$, respectively. 


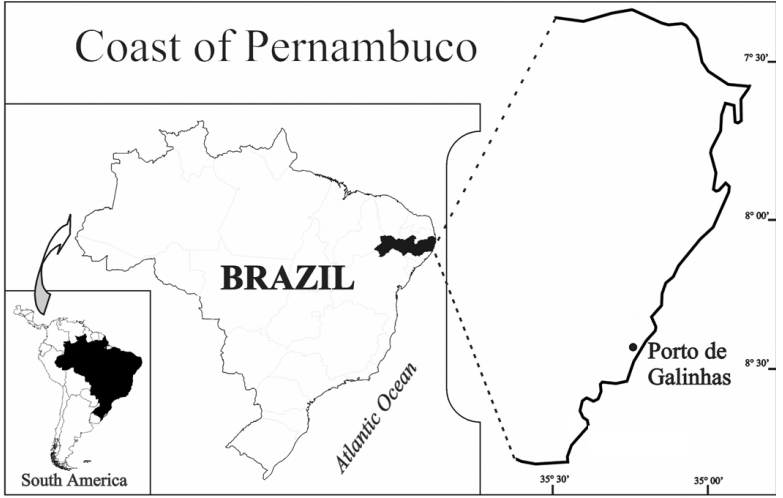

Fig. 1- Geographic localization of Porto de Galinhas beach in the coast of Pernambuco State, Brazil

\section{Methodology}

Specimens were collected during low tide in January (dry season) and June 2006, and in March 2007 (wet season). As the plankton can vary significantly among different depths due especially to the resuspension from the bottom, surveys are carried out at 2 and $6 \mathrm{~m}$ deep. Randomly, 30 colonies were collected in each survey. The samples were fixed in field with formaldehyde $10 \%$ to stop digestion. Sampling was always undertaken between 09:00 and 10:30 a.m. to avoid potential variation in the stomach content associated to circadian rhythms.

The content of 35 polyps selected at random from each sampling month and bathymetry was isolated through dissection under a binocular and a light microscope, and then identified, where feasible to taxa, measured and counted.

Qualitative plankton samples were collected concurrently with the collection of $C$. riisei colonies to study annual plankton variation. Plankton net $20 \mathrm{~cm}$ in diameter with a mesh size of 60 $\mu \mathrm{m}$ were employed. The nets were towed over a distance of $40 \mathrm{~m}$ by a SCUBA diver, close (30-50 $\mathrm{cm})$ to the octocoral community at the two studied depths ( 2 and $6 \mathrm{~m}$ ). The plankton was immediately transferred into formaldehyde diluted to $4 \%$ in seawater for later counting and identification to the main taxonomic groups.

\section{DATA TREATMENT}

Food size selectivity was evaluated comparing prey sizes from two origins (C. riisei polyps and plankton) on all samplings (January 2006, June 2006 and March 2007) and depths (2 and $6 \mathrm{~m}$ ) using GLM 3-way ANOVA 2x3x2 test followed by Tukey's test (Hill and Lewicki 2006). Data were transformed (lognormal) to fit to the model. A comparative distribution histogram of prey size in the plankton and in the polyps was designed.

Spearman's correlation (Sokal and Rohlf 1995) was used to examine the relationship between prey abundance in polyps and in the plankton.

All tests were performed with Statistica v. 7.0 software (StatSoft, Tulsa, OK, USA).

Ivlev's electivity index (E) was calculated for the most representative preys as: $\mathrm{E}=(\mathrm{r}-\mathrm{p}) /(\mathrm{r}+\mathrm{p})$, where $r$ is the frequency of a given prey in the diet and $p$ is its frequency in the natural prey population (Barange 1988).

\section{RESULTS}

The most abundant items found in the polyp gastric cavity and in the plankton were diatoms and cyanophytes. Besides Divisions Cyanophyta and Bacillariophyta, other items were found in the polyp gastric cavity, such as mollusks, foraminifers, rotifers, radiolarians, tintinids, crustaceans, nematodes and invertebrate eggs (Table I).

Porifera spicules and many Crustacea fragments, especially appendages, were also found in C. riisei polyps.

The size of available prey in the plankton ranged from 10 to $3,820 \mu \mathrm{m}$, a similar amplitude to those found in the cavity of the polyps ( 7 to $4,270 \mu \mathrm{m})$. Despite all the sizes classes present in the plankton been represented in the polyps, only the smaller preys $(<150 \mu \mathrm{m})$ are more frequent in the polyps than in the plankton (Fig. 2). Due to this, the mean prey size in the polyps $(112.7 \mu \mathrm{m})$ was significantly lower than the value found in the plankton $(240.5 \mu \mathrm{m})\left(\mathrm{F}_{1,8524}=110.11 ; \mathrm{p}<0.001\right)$. 
TABLE I

Relative abundance (\%) of prey items in the plankton and in the gastric cavities of the polyps of Carijoa riisei during the sampling period in Porto de Galinhas beach

\begin{tabular}{|c|c|c|c|c|c|c|c|c|c|c|c|c|c|}
\hline \multirow[b]{3}{*}{ PREY ITEMS } & \multicolumn{4}{|c|}{ January } & \multicolumn{4}{|c|}{ June } & \multicolumn{4}{|c|}{ March } & \multirow{3}{*}{ Total } \\
\hline & \multicolumn{2}{|c|}{ Polyp } & \multicolumn{2}{|c|}{ Plankton } & \multicolumn{2}{|c|}{ Polyp } & \multicolumn{2}{|c|}{ Plankton } & \multicolumn{2}{|c|}{ Polyp } & \multicolumn{2}{|c|}{ Plankton } & \\
\hline & $2 m$ & $6 \mathrm{~m}$ & $2 m$ & $6 \mathrm{~m}$ & $2 m$ & $6 \mathrm{~m}$ & $2 m$ & $6 m$ & $2 m$ & $6 \mathrm{~m}$ & $2 m$ & $6 m$ & \\
\hline Mollusca & 0.16 & 0.91 & -- & 1.06 & 0.19 & 0.08 & -- & 0.58 & 0.08 & -- & 1.68 & -- & 0.003 \\
\hline Foraminifera & -- & 0.15 & 0.22 & 1.06 & -- & 0.92 & -- & 1.17 & 0.08 & 0.30 & 0.56 & 0.93 & 0.003 \\
\hline Rotifera & 0.08 & 0.08 & 0.22 & -- & 0.28 & 1.34 & 6.76 & 0.58 & 0.38 & 1.65 & -- & 0.23 & 0.005 \\
\hline Invertebrates eggs & 0.16 & -- & -- & -- & 0.35 & -- & -- & -- & -- & -- & 1.12 & 0.23 & 0.001 \\
\hline Porifera (spicules) & 5.41 & 1.82 & 2.20 & 5.63 & 10.34 & 3.93 & 2.70 & 32.16 & 1.58 & 5.56 & 14.53 & 46.53 & 0.072 \\
\hline Crustacea & 0.08 & 0.23 & 16.96 & 9.51 & 0.09 & 0.67 & -- & 1.17 & 0.53 & 1.20 & 3.91 & 2.08 & 0.018 \\
\hline Fragments of crustaceans & 1.11 & 2.27 & 1.54 & 8.45 & 2.16 & 1.92 & 2.70 & 5.26 & 6.53 & 21.50 & 3.91 & 1.16 & 0.044 \\
\hline Tintinnida & -- & -- & 0.44 & -- & -- & -- & -- & -- & -- & 0.15 & -- & -- & 0.001 \\
\hline Cyanophyceae & 41.02 & 30.38 & 19.82 & 35.56 & 30.64 & 62.68 & 25.68 & 34.50 & 73.52 & 16.99 & 38.55 & 24.07 & 0.419 \\
\hline Diatoms & 50.87 & 62.73 & 58.37 & 36.27 & 53.85 & 9.12 & 58.11 & 23.39 & 16.05 & 47.22 & 29.61 & 24.07 & 0.390 \\
\hline Nematoda & 0.16 & 0.38 & -- & -- & -- & 2.34 & -- & -- & 0.15 & -- & 0.56 & 0.23 & 0.005 \\
\hline Unidentified & 0.95 & 1.06 & 0.22 & 2.11 & 2.44 & 16.99 & 4.05 & 1.17 & 0.13 & 5.41 & 5.59 & 0.23 & 0.40 \\
\hline Total & 0.15 & 0.16 & 0.05 & 0.03 & 0.13 & 0.14 & 0.1 & 0.02 & 0.16 & 0.08 & 0.02 & 0.05 & \\
\hline
\end{tabular}

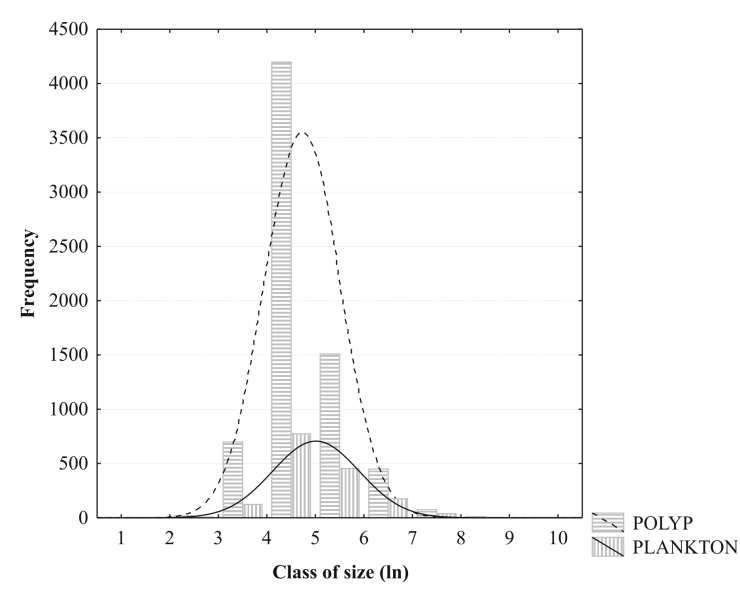

Fig. 2- Size-frequency histogram of prey found in gastric cavities of the polyps of Carijoa riisei and in the plankton at Porto de Galinhas beach

On comparing prey sizes from these sites (polyps vs. plankton) and from the studied months, the following pattern was observed: both in polyps and plankton, the mean prey size in January and March was not significantly different, but was significantly greater than that from June (Fig. 3). On the other hand, there was no significant difference in prey size between the studied depths, but in both depths significant different prey sizes were found between polyps vs. plankton ( $p<0.005$, Fig. 4).

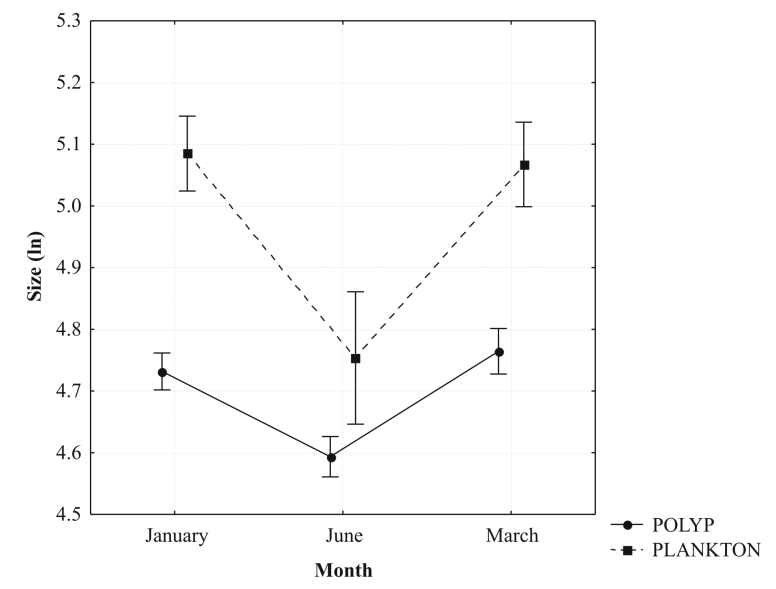

Fig. 3- First-order interaction between sites (polyps of Carijoa riisei and plankton) and months on $\ln$ transformed mean of prey size at Porto de Galinhas beach 


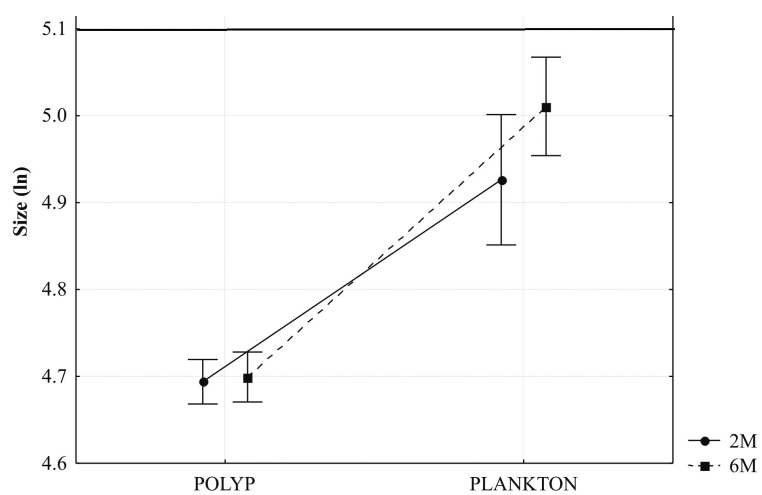

Fig. 4- First-order interaction between sites (polyps of Carijoa riisei and plankton) and depth on $\ln$ transformed mean of prey size at Porto de Galinhas beach

A second order interaction was observed in prey size of different sites (polyps vs. plankton), depths and months $\left(\mathrm{F}_{2,8524}=21.426 ; \mathrm{p}<0.001\right)$, with the inverse behavior occurring in March, when prey sizes were significantly greater at 2 meters $(p<0.005)$ both in the plankton and in C. riisei polyps, and a more homogeneous sizes in January, again both in the plankton and in the polyps (Fig. 5).
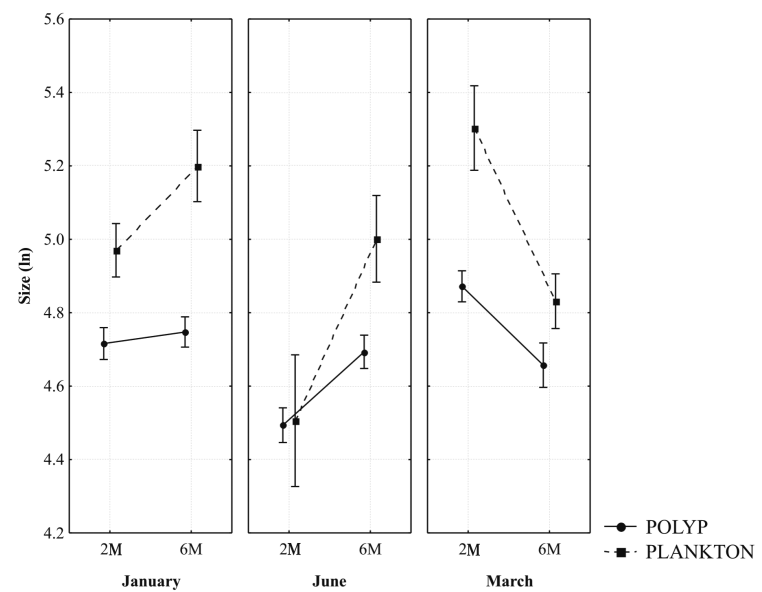

Fig. 5- Second-order interaction among sites (polyps of Carijoa riisei and plankton), months and depth on $\ln$ transformed mean of prey size in Porto de Galinhas beach

A positive correlation was observed between available prey abundance in the plankton and inside $C$. riisei polyp gastric cavity ( $\mathrm{rs}=0.33$, $\mathrm{p}=0.0002$; Fig. 6). Both outliers showed in the graphic indicate species that showed a remarkable abundance in polyps, the diatom Mastogloia sp. $(2,041 ; 23.96 \%)$ and the cyanophyte Oscillatoria $s p(3,171 ; 33.96 \%)$. However, Oscillatoria sp. was abundant in both the plankton $(22.93 \%)$ and gastric cavity, opposed to Mastogloia sp., which showed very few individuals in the plankton $(0.19 \%)$.

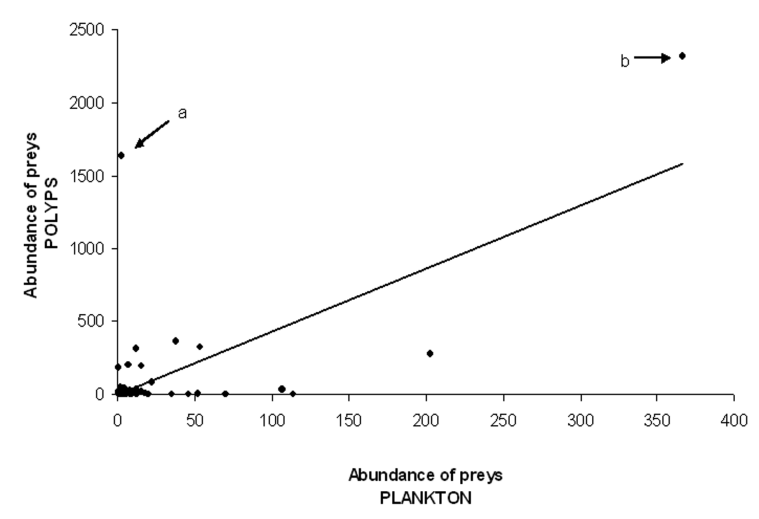

Fig. 6- Spearman correlation coefficient between total abundances of prey items found in gastric cavities of the polyps of Carijoa riisei and in the plankton at Porto de Galinhas beach. Outliers: a, Mastogloia sp; b, Oscillatoria $s p$

As a result of the high amount of Mastogloia $s p$. inside the polyps, the species showed higher positive selectivity according do Ivlev's index (Table II). The other two diatom species and two cyanophytes also showed high positive selectivity (Table II).

Although not being abundant in the gastric cavity, some zooplankton species showed high positive selectivity: Nematoda (0.93), a Copepoda species (0.769) and Rotifera (0.704).

TABLE II Ivlev's electivity index (E) of the six most important food items found in gastric cavities of the polyps of Carijoa riisei during the sampling period in Porto de Galinhas beach (values $>0$ represent positive, and values $<0$ negative selection)

\begin{tabular}{ll}
\hline PREY ITEMS & E \\
\hline Mastogloia $s p$. & 0.996 \\
Mastogloia sp. & 0.927 \\
Grammatophora oceanica & 0.850 \\
Lyngbya sp. & 0.809 \\
Oscillatoria sp. & 0.727 \\
Fragments of crustaceans & 0.711 \\
\hline
\end{tabular}


Analyzing the prey items found inside the gastric cavity, some benthonic elements were found, among them four foraminifer species, two harpacticoid copepod species and diatoms Grammatophora hamulifera, Rhabdonema adriaticum, Podocystis adriatica and Paralia sulcata, as well as sponge spicules. These items were found both at 2 and $6 \mathrm{~m}$ deep and showed $0.51 \%$ relative abundance of all preys consumed by the octocorals. It is likely that some items that were not identified to specific level are also benthonic organisms since many cited genera have benthonic species.

\section{DISCUSSION}

According to Jacksic(1989), a species maybe defined as opportunistic when consumes some or all preys according to their abundance in the environment. This study recorded a correlation between prey abundance in the water column and its occurrence in the gastrovascular content of the octocoral $C$. riisei, demonstrating an opportunistic behavior. This species prey on a wide range of organisms, but preferently on diatoms and cyanophytes that were the most abundant preys in the plankton, which endorses the opportunistic behavior. Even nonfood items present in the resuspended water were captured in the same proportion by the octocoral, such as sponge spicules.

The variety of prey types found in the plankton and polyps was the same (Table I), demonstrating the great amplitude of $C$. riisei trophic niche, although Coma et al. (1994) found a reduced prey variety in Paramuricea clavata diet when compared to that available in the plankton.

In their studies, Ribes et al. (2003) suggest that the ingestion of phytoplankton prey by octocorals depends both on prey size and abundance. The ingestion of greater, not abundant items (diatoms) was similar to that of the smaller, abundant nanoflagellates. Similar results were found in this study, where the smaller items, in this case diatoms, were the most abundant (Table I).
Samples of June had the lowest prey sizes in both the polyps and in the plankton. This is the wettest month on the coast of Pernambuco and this may affect the type and quantity of each item of prey available, due to resuspension and seasonal variation of abundance of planktonic species. The second order interaction in prey size observed among sites (polyps and plankton), depths and months (Fig. 5) showed that the three parameters contributed for the observed pattern.

$C$. riisei uses all the size categories of prey available in the plankton, and the size frequency distribution between polyps and plankton was similar (Fig. 2). Nevertheless, preys of smaller sizes are used in greater quantities by the octocoral. This is why the mean prey size was smaller than the mean size of all the organisms in the plankton, Thus, the study indicates some size selectivity in this species or at least size limitation. $C$. riisei has a pinned tentacular crown that would act, in fact, as a filtration surface (Hughes 2001), though limiting maximum prey size. However, some large preys such as nematodes $(448 \mathrm{~mm})$ had high levels of selectivity (0.93). This may be related to the shape of the prey that can increase its chances of being trapped in the tentacular crown.

The opportunistic character is a common feature among passive suspensivorous animals. Predominant preys are usually the less motile ones (Coma et al. 1994, Ribes et al. 2003) and this character, alongside the "mesh size" of the tentacular surface, seems to be the major prey selector. This can be easily visualized with crustaceans, mainly very motile copepods, which are found in great number in the plankton, but were not abundant in the polyps; this is the opposite of the observed with nematodes, which have low motility, were scarce in the plankton and very abundant in the polyps. C. riisei showed preference for small, not very motile preys and consequently, the more abundant Copepoda species in the gastric cavity was that with lower mean size among crustaceans. 
According to Lasker (1981), three gorgonian species found it difficult to capture zooplankton items, which would limit captures to a small portion of the zooplankton with low motility.

Resuspension hydrodynamic processes have a major role in making food resources available, thus influencing the diet of species from certain regions (Genzano 2005). Hence, benthonic diatoms are the main prey of the subantarctic hydroid Silicularia rosea (Gili et al. 1996), as well as benthonic amphipods are for the hydroid Tubularia crocea in the Argentinean intertidal zones (Genzano 2005).

Water movement in intertidal zones resulting from waves and currents re-suspend typical benthonic organisms to the water column, making exogenous food items available to the plankton. This study found few, low abundant $(0.51 \%)$ benthonic elements in C. riisei diet, which leads to the conclusion that the greater food income of the octocoral is planktonic.

Thus, the octocoral C. riisei incorporates energy mainly, but not exclusively, from the plankton and transfers it to higher levels of the pelagic trophic web, such as the reefal fishes (Pérez, personal observation) and the polychaeta Hermodice carunculata (Souza et al. 2007), besides making the energy available in its reproductive stages (eggs and larvae), which are part of the diet of many pelagic, planktonic and benthonic organisms.

From the results, it is possible to conclude that the octocoral $C$. riisei, in the Brazilian northeast coast, is an opportunistic polyphagous species with suspensivorous passive filtrating feeding habit with a preference for small prey items. Besides, its major role in the reefal ecosystem is evidenced, since it is a bidirectional energy transfer between pelagic and benthonic environments.

\section{ACKNOWLEDGMENTS}

We thank the following for helping with specimens identifications: Leandro Ferreira, Gabriela Oliveira e Gloria Silva-Cunha (Oceanografia-UFPE). Raftmen Junior of Porto de Galinhas, Porto Point Dive
Shop, Aquaticus, LACMAR (Zoologia-UFPE), Bárbara Neves (GPA-UFPE) and Gabriel Genzano (UNMdP, Argentina) for their invaluable assistance with the field and laboratory work. Coordenação de Aperfeiçoamento de Pessoal de Nível Superior (CAPES, Brazil) for the Master research fellowship of Ana Karla Lira. This work was funded by Conselho Nacional de Desenvolvimento Científico e Tecnológico (CNPq) (Edital MCT/CNPq 14/2008 - Universal, Processo 480478/2008-2).

\section{RESUMO}

Este estudo foi desenvolvido para avaliar a seletividade de presas (tipo e tamanho) do octocoral Carijoa riisei na praia de Porto de Galinhas, nordeste do Brasil, relacionando a disponibilidade de presas no plâncton com o conteúdo gástrico dos pólipos. Diatomáceas e Cianofíceas foram os itens de presas mais abundantes tanto na cavidade gástrica dos pólipos quanto no plâncton. Foi observada uma correlação entre a abundância de presas no plâncton e na cavidade gástrica dos pólipos de C. riisei. Mastogloia sp. apresentou o maior índice de seletividade positiva $(0,99)$. Foram encontrados organismos bentônicos, totalizando $0,51 \%$ do total de presas consumidas. A amplitude de tamanho das presas no plâncton foi similar à da cavidade gástrica dos pólipos, no entanto, o tamanho médio das presas nos pólipos $(112,7 \mu \mathrm{m})$ foi significativamente menor que a do plâncton $(240,5 \mu \mathrm{m})$. Assim, o estudo indica certa seletividade de tamanho nesta espécie ou, pelo menos, limitação de tamanho. A partir dos resultados, conclui-se que o octocoral C. riisei é uma espécie polífaga oportunista na costa nordestina brasileira, com hábito alimentador suspensívoro passivo, preferindo itens de presas com pequeno tamanho e evidenciando ter importante papel ecológico em ecossistemas recifais como responsável pela transferência bidirecional de energia entre as zonas pelágica e bentônica.

Palavras-chave: Alcyonacea, alimentação natural, seletividade de presas, disponibilidade de presas, ecologia trófica. 


\section{REFERENCES}

BARANGE M. 1988. Prey selection and capture strategies of the benthic hydroid Eudendrium racemosum. Mar Ecol Prog Ser 47: 83-88.

COMA R, Gili J-M, ZABAla M AND RIERA T. 1994. Feeding and prey capture cycles in the aposymbiotic gorgonian Paramuricea clavata. Mar Ecol Prog Ser 115: 257-270.

DAY JR JW, Hall CAS, KemP WM AND YÁNEZ-ARANCIBIA A. 1989. Estuarine Ecology. New York: J Wiley \& Sons, $558 \mathrm{p}$.

GENZANO GN. 2005. Trophic ecology of a benthic intertidal hydroid, Tubularia crocea, at Mar del Plata, Argentina. Mar Biol 85: 307-312.

Gili J-M, Alva V, Coma R, Orejas C, Pages F, Ribes M, ZABALA M, ARNTZ W, BOUILLION J, BOERO F AND HuGHES RG. 1997. The impact of small benthic passive suspension feeders in shallow marine ecosystems: the hydroids as an example. Zool Verhand 323: 99-105.

GILI J-M AND COMA R. 1998. Benthic suspension feeders: their paramount role in littoral marine webs. Trends Ecol Evol 13: 316-321.

Gili J-M, Hughes RG AND Álva V. 1996. A quantitative study of feeding by the hydroid Tubularia larynx Elis and Solander, 1786. Sci Mar 60: 43-54.

HiLl T AND LEWICKI P. 2006. Statistics: Methods and Application, $1^{\text {st }}$ ed., Tulsa: StatSoft, $832 \mathrm{p}$.

HuGHES D. 2001. A review of biological filtration by marine invertebrates. In: BIOFAQs A review of the environmental impacts of marine cage aquaculture, processes of biofiltration relevant to impact mitigation, the biological properties of marine invertebrates relevant to biofiltration. Annual Report to the European Commission, EU Project Q5RS-2000-30305.

JACKSIC FM. 1989. Opportunism in selectivity among carnivorous predators that eat mammalian prey: a statistical test of hypotheses. Oikos 56: 427-430.
LASKER HR. 1981. A comparison of the particulate feeding abilities of three species of gorgonian soft coral. Mar Ecol Prog Ser 5: 61-67.

Lira AK, NAud J-P, Gomes PB, SANTOS AM AND PEREZ CD. 2009. Trophic ecology of the octocoral Carijoa riisei from littoral of Pernambuco, Brazil. I. Composition and spatio-temporal variation of the diet. J Mar Biol Ass UK 89: 89-99.

Migné A AND Davoult D. 2002. Experimental nutrition in the soft coral Alcyonium digitatum (Linnaeus, 1758). Cah Biol Mar 43: 9-16.

Neves BM, Lima EJB AND Perez CD. 2007. Brittle stars associated (Echinodermata: Ophiuroidea) with the octocoral Carijoa riisei (Cnidaria: Anthozoa) from the littoral of Pernambuco, Brazil. J Mar Biol Ass UK 85: $307-312$

Ribes M, COMA R AND Rossi S. 2003. Natural feeding of the temperate asymbiotic octocoral-gorgonian Leptogorgia sarmentosa (Cnidaria: Ocotocorallia). Mar Ecol Prog Ser 254: 141-150.

Rossi S, RiBes M, COMA R AND GILI J-M. 2004. Temporal variability in zooplankton prey capture rate of the passive suspension feeder Leptogorgia sarmentosa (Cnidaria: Octocorallia), a case study. Mar Biol 144: 89-99.

SOKAL RR AND ROHLF FJ. 1995. Biometry: the principles and practice of statistics in biological research, $3^{\text {rd }}$ ed., New York: W. H. Freeman and Co., 887 p.

Souza JRB, Rodrigues HA, Neves BM ANd Perez CD. 2007. First report of bristleworm predator of the reef octocoral Carijoa riisei. Coral Reefs 26: 1033.

Tsounis G, Rossi S, LAUdien J, Bramanti L, FERnANDEZ N, GILI J-M AND ARNTZ W. 2005. Diet and seasonal prey capture rates in the Mediterranean red coral (Corallium rubrum L.). Mar Biol 149: 313-325. 